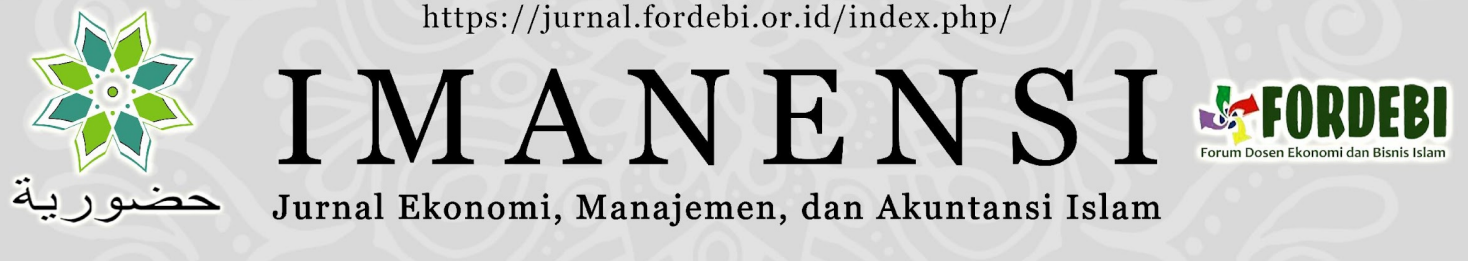

\title{
PERSEPSI MAHASISWA AKUNTANSI NON MUSLIM TERHADAP AKUNTANSI SYARIAH
}

\author{
Siti Nur Anisa ${ }^{\mathrm{a}, 1}$, Jurana ${ }^{\mathrm{b}, 2^{*}}$, Muh. Darma Halwi ${ }^{\mathrm{c}, 3}$, Abdul Kahar ${ }^{\mathrm{d}, 4}$, \\ Muhammad Ilham Pakawaru ${ }^{\mathrm{e}, 5}$, Masruddin ${ }^{\mathrm{f}, 6}$. \\ a,b,c,d,e,f Universitas Tadulako, J1.Soekarno Hatta No Km 9 Tondo-Palu, 94148, Indonesia \\ 1Sitinuranisa.amruna@gmail.com; 2 jurananurdin@gmail.com *; 3 darmahalwi.borang@gmail.com; \\ Kaharabdu1987@gmail.com4; pakawaruilham4@gmail.com5; masruddin.untad@gmail.com6
}

*Corresponding author

\author{
INFO ARTIKEL \\ IMANENSI \\ Volume 7 \\ Nomor 1 \\ Halaman 53-63 \\ Malang, Maret 2022 \\ ISSN: 2339-1847 \\ e-ISSN: 2683-9968

\section{Kronologi Artikel: \\ Tanggal Masuk: \\ 10 Desember 2021 \\ Tanggal Revisi: \\ 20 Februari 2022 \\ Tanggal Diterima: \\ 5 Maret 2022} \\ Kata Kunci: \\ Akuntansi Syariah; \\ Fenomenologi; \\ Kurikulum; \\ Pendidikan Akuntansi.

\section{Keywords:} \\ Accounting Education; \\ Curriculum; \\ Phenomenology; \\ Sharia Accounting.
}

\begin{abstract}
Abstrak: Persepsi Mahasiswa Akuntansi Non Muslim Terhadap Akuntansi Syariah. Penelitian ini bertujuan untuk mengetahui persepsi mahasiswa akuntansi non muslim mengenai akuntansi Syariah. Pendekatan fenomenologi transcendental dipilih sebagai pendekatan penelitian. Peneliti mengumpulkan data dengan melakukan wawancara mendalam dan observasi terhadap mahasiswa S1 jurusan akuntansi non muslim di Kota Palu. Hasil dari penelitian menunjukan bahwa masing-masing informan memiliki pemahaman berbeda mengenai Akuntansi Syariah, hal ini dikarenakan kurangnya pemahaman mengenai istilah dalam Akuntansi Syariah, ketidaktertarikan terhadap mata kuliah Akuntansi Syariah akibat perbedaan agama yang dianut. Implikasi penelitian sebagai masukan akademisi dalam mengajar bukan sekedar transfer knowledge, tetapi yang utama adalah transfer value karena merupakan sarana dakwah dan tanggung jawab akademisi untuk tidak memisahkan nilai agama dari keilmuan akuntansi.
\end{abstract}

\begin{abstract}
Perceptions of Non-Muslim Accounting Students Against Sharia Accounting. This study aims to determine the perception of non-Muslim accounting students regarding Islamic accounting. The transcendental phenomenology approach was chosen as the research approach. Researchers collected data by conducting in-depth interviews and observations of undergraduate students majoring in non-Muslim accounting in Palu City. The results of the study show that each informant has a different understanding of Islamic Accounting, this is due to a lack of understanding of the terms in Islamic Accounting, disinterest in Islamic Accounting courses due to differences in religion. The implications of research as input for academics in teaching are not just transfer knowledge, but the main thing is transfer values because it is a means of preaching and it is the responsibility of academics not to separate religious values from accounting science.
\end{abstract}




\section{PENDAHULUAN}

Mata kuliah Akuntansi Syariah mulai diajarkan sejak tahun 2000an di beberapa perguruan tinggi di Indonesia. Keadaan ini diungkapkan Rini (2018) saat mewawancarai sebagian pengajar Akuntansi Syariah, baik di seminar/workshop Akuntansi Syariah maupun pertemuan keilmuan akuntansi lainnya. Selain itu hasil pencarian rencana pendidikan Program Studi Akuntansi Syariah di Indonesia mulai diajarkan pada tahun 2000-2007 di Universitas Trisakti, Universitas Brawijaya, Universitas Islam Indonesia, Universitas Indonesia dan Universitas Islam Negeri Syarif Hidayatullah Jakarta. Sejak awal, tokoh-tokoh yang memperkenalkan Akuntansi Syariah di Indonesia adalah Almarhum Sofyan Syafri Harahap, Iwan Triyuwono dan Muhammad Akhyar Adnan. Ketiga tokoh Akuntansi Syariah ini selalu mengisi seminar, menyusun bahan bacaan dan menulis artikel tentang Akuntansi Syariah, kemudian perguruan tinggi lainnya ikut mengajarkan mata kuliah Akuntansi Syariah [Rini,2018].

Dokumen tertulis yang menyimpulkan dan mencerminkan perjuangan untuk kemajuan Akuntansi Syariah masih sangat terbatas jumlahnya. Apalagi dengan latar belakang sejarah kemajuan Akuntansi Syariah di Indonesia. Kekurang tertarikan dari banyak orang yang melihat masalah ini baik sebagai komponen kehidupan eksplorasi dan sebagai informasi membuat latar belakang sejarah Akuntansi Syariah masih sangat kecil untuk ditemukan (Khaddafi et al., 2017). Mukhtaruddin dan Dina (2004) mengungkapkan bahwa perkembangan Akuntansi Syariah yang sangat pesat akan sangat mempengaruhi bidang Pendidikan, khususnya pendidikan akuntansi. Realitas saat ini membuat pihak akademisi melirik kembali kurikulum yang telah disusun sebelumnya, terlepas dari apakah program pendidikan yang ada saat ini telah memberikan kontribusi bagi lulusannya sehingga mereka dapat bersaing di ranah kerja (Wijaya, 2013).

Ludigdo (2009) mengungkapkan akhir-akhir ini perkembangan institusi syariah semakin pesat. Kebutuhan tenaga profesional serta ahli di bidang ini sangat dibutuhkan, untuk mengatasi kemajuan bisnis berbasis syariah dan yang pasti akan membutuhkan pengembangan Akuntansi Syariah, di Indonesia kemajuan bisnis syariah sangat pesat, berawal dari bank Muamalat yang menjadi bank syariah pertama di Indonesia, kini telah ada bank umum syariah serta unit syariah, lembaga keuangan Mikro syariah, Baitul Maal, serta asuransi syariah, serta hotel bercirikan syariah mulai menyebar saat ini. Kemajuan dunia bisnis syariah di Indonesia, tentu harus bersamaan dengan infrastruktur yang memadai, termasuk tenaga ahli yang membidangi bisnis syariah itu sendiri (Febriantoro, 2013).

Program Studi S1 Akuntansi merupakan salah satu Jurusan yang berada dalam lingkungan Fakultas Ekonomi dan Bisnis Universitas Tadulako, Jurusan Akuntansi menjadi terfavorit di Universitas Tadulako sampai saat ini. Mahasiswa Jurusan Akuntansi Fakultas Ekonomi dan Bisnis Universitas Tadulako wajib mengikuti perkuliahan pada mata kuliah Akuntansi Syariah yang diprogram pada semester empat. Mahasiswa Jurusan Akuntansi beragam baik dari segi suku bangsa dan agama Katolik, Protestan, Hindu, Budha, dan Konghucu, walaupun lebih didominasi oleh mahasiswa yang beragama Islam. Triyuwono (2012) mengungkapkan Akuntansi Syariah merupakan mata kuliah yang meleburkan dinding sekularisme dan menegakkan kembali perhatian kepada Tuhan, sehingga mata kuliah tersebut memiliki ruh, Akuntansi Syariah mengeluarkan prinsip pada lulusannya agar memiliki sikap kewajiban yang merefleksikan bahwa manusia sebagai bagian yang dipantau oleh Tuhan sebagai stakeholder tertinggi.

Keberadaan mata kuliah Akuntansi Syariah di Jurusan Akuntansi ditujukan bukan hanya menyiapkan tenaga profesional dan ahli di bidang ini. Namun lebih dari itu, pembelajaran Akuntansi Syariah dapat membentuk lulusan untuk 
memahami hakikat dirinya sebagai khalifatullah fil ardh (Triyuwono, 2012). Jurusan Akuntansi Fakultas Ekonomi dan Bisnis Universitas Tadulako saat ini menjadikan mata kuliah Akuntansi Syariah sebagai salah satu mata kuliah wajib di Jurusan Akuntansi. Berdasarkan kondisi ini, peneliti melakukan studi fenomena pada mahasiswa non muslim Jurusan Akuntansi Fakultas Ekonomi dan Bisnis Universitas Tadulako. Adapun Penelitian ini bertujuan untuk mengetahui mengenai persepsi mahasiswa akuntansi non muslim mengenai akuntansi Syariah.

\section{METODE}

Paradigma penelitian ini menggunakan penelitian kualitatif dengan pendekatan fenomenologi, dengan Paradigma Interpretif dan pendekatan fenomenologi transendental. Dalam pengkajian fenomenologi transendental, yang selama siklus menonjolkan subjektivitas dan mengungkap perwujudan keterlibatan dalam pendekatan metodis, ada lima bagian yaitu noesis, neoma, epoche, intentional analysis, eidetic reduction. Objek penelitian yang akan diteliti yaitu pemahaman Akuntansi Syariah dari sudut pandang mahasiswa non muslim, yang menurut peneliti mempunyai pendapat yang berbeda-beda antara satu dengan yang lainnya. Informan dalam penelitian ini berjumlah 5 orang merupakan mahasiswa yang telah mengambil mata kuliah Akuntansi Syariah di Program Studi S1 Akuntansi. Penelitian ini dilakukan pada mahasiswa non muslim di Program Studi S1 Akuntansi. Lokasi penelitian dalam pengkajian ini adalah di Program Studi S1 Akuntansi. Jl. Setia Budi, Kota palu, Sulawesi Tengah, karena peneliti merupakan mahasiswa Universitas Tadulako. Jenis data yang digunakan adalah jenis data kualitatif. Informasi yang digunakan dalam ulasan ini adalah jenis data primer. Data primer adalah informasi yang didapatkan secara langsung pada objek pengkajian tanpa melewati pihak ketiga. Objek penelitian ini adalah mahasiswa non muslim Program Studi S1 Akuntansi.

Wawancara digunakan untuk mengetahui secara langsung hal-hal dari informan secara mendalam yang berhubungan dengan topik yang dikaji yaitu Pemahaman Akuntansi Syariah Dari Sudut Pandang Mahasiswa non muslim Program Studi S1 Akuntansi. Dalam penelitian ini, yang menjadi informan ialah mahasiswa non muslim angkatan 2017 yang berjumlah lima orang dan telah mengambil mata kuliah Akuntansi Syariah di Program Studi S1 Akuntansi yang sengaja dipilih oleh peneliti. Peneliti melakukan wawancara berdasarkan tiga kriteria informan yang ideal menurut Lawrence (2007) yaitu: (1) Informan sangat akrab atau familiar dan menyaksikan peristiwa penting yang terkait dengan isu yang diangkat; (2) Informan tersebut terlibat langsung dalam masalah yang diteliti; (3) Informan memiliki waktu yang cukup untuk melakukan wawancara (interaksi) dengan peneliti.

Analisis data yang digunakan pada penelitian ini yaitu sesuai dengan pendekatan fenomenologi seperti yang digambarkan Kamayanti (2016). Terdapat empat fase pada penyelidikan fenomenologi. Tahap pertama menggambarkan fenomena dari hasil wawancara yang telah direkam. Catatan pertemuan mengenali dan menggambarkan sifat pengalaman dan perhatian informan. Tahap selanjutnya adalah mengenali topik yang terlihat pada uraian di bagian awal. Tahap ketiga noema dan noesis. Noema artinya apa yang disadari dan Noesis artinya tindakan kesadaran. Noema adalah pernyataan objektif dari perilaku atau pengalaman sebagai realitas, sedangkan Noesis merupakan refleksi subyektif (kesadaran) dari pernyataan yang obyektif tersebut. Tahap keempat dalam pemeriksaan informasi fenomenologi ialah merangkum inti pada korelasi antara noema dan noesis. Teknik kesimpulan ini disebut eidetic reduction dapat menggunakan kertas kerja analisis fenomenologi transendental. 


\section{HASIL DAN PEMBAHASAN}

\subsection{Persepsi Mahasiswa Nilam terhadap Akuntansi Syariah}

Mahasiswa non muslim yang telah menempuh mata kuliah Akuntansi Syariah mempunyai pendapat dan pemahaman masing-masing dalam memaknai mata kuliah Akuntansi Syariah. Untuk mengetahui bagaimana pendapat mahasiswa non muslim tentang mata kuliah Akuntansi. Peneliti menggali pendapat seorang informan sebut saja Nilam, yang beragama Hindu menyatakan pendapatnya mengenai mata kuliah Akuntansi Syariah:

"Kalau menurut pendapatku sih apa ee, tidak apa-apa karena diwajibkan juga jadi harus diikuti. Kalau [untuk pendapat tentang mata kuliah Akuntansi Syariah yah pasti bagus karena yang diajarkan pelajaran tentang akuntansinya cuman lebih ke agama Islamnya."

Pernyataan (noema) Nilam, peneliti memperoleh informan telah mengetahui Akuntansi Syariah tetapi menurut Nilam akuntansi yang lebih fokus ke agama Islam. Kemudian peneliti mengajukan pertanyaan sebagai mahasiswa non muslim apa yang anda pahami setelah mempelajari mata kuliah Akuntansi Syariah. Nilam berpendapat:

"Eeehh, apa yah [kalau dalam Syariah itu ternyata riba itu dilarang.]"

"pemahaman ku Akuntansi Syariah itu sih merupakan [akuntansi berdasar dari ajaran agama Islam.]"

Pernyataannya (noesis) Nilam peneliti memperoleh bahwa riba dalam Akuntansi Syariah dilarang atau diharamkan dan dasar akuntansinya berdasar dari ajaran agama Islam. Peneliti melanjutkan pertanyaan apa kesulitan yang didapatkan pada saat mengikuti mata kuliah Akuntansi Syariah. Informan Nilam berpendapat:

"Kesulitannya itu [kaya memahami hukum-hukumnya seperti itu terus juga kalau untuk bukunya itu biasa di Akuntansi Syariah itu ada tulisan arab jadi kurang bisa saya baca dan tulisan bacaan-bacaan arabnya juga tidak bisa saya baca dan memahami juga kurang."

Peneliti bertanya kembali bagaimana pendapat mahasiswa non muslim terhadap mata kuliah Akuntansi Syariah di masa mendatang. Informan Nilam menyatakan pendapatnya:

"Eeehh, kalau misalnya ini memang kedepannya memang diharuskan yaa, tidak apa-apa sih [tapi kalau misalnya untuk kedepannya tidak diharuskan yaa menurut ku dihilangkan saja sih hahaha]."

"Itanggapannya bagus sih tapi kalau boleh mending tidak usah ada mata kuliah ini karena sulit dipahami.]"

Jawaban tersebut merefleksikan epoche informan, tampaknya informan Nilam, adanya tulisan arab dan istilah-istilah yang belum pernah mereka dengar sebelumnya yang membuat mahasiswa non muslim kesulitan dalam mata kuliah Akuntansi Syariah. Menurut informan mata kuliah Akuntansi Syariah dijadikan mata kuliah pilihan karena tidak semua mahasiswa non muslim mau menerima dan mengikuti perkuliahan. informan Nilam diatas menunjukan bahwa informan memiliki kesulitan dalam memahami mata kuliah Akuntansi Syariah, adanya kesulitan dan kurangnya pemahaman mereka terhadap mata kuliah Akuntansi Syariah yang membuat informan mengusulkan bahwa mata kuliah Akuntansi Syariah untuk menjadi mata kuliah pilihan. 
Intentional Analysis menunjukan bahwa sebagaimana yang terjadi pada informan Nilam, proses perkuliahan membentuk pemahaman Nilam atas Akuntansi Syariah menurutnya mata kuliah Akuntansi Syariah itu akuntansi yang lebih ke agama Islam dan kesulitan informan pada proses perkuliahan yaitu pada istilahistilah Akuntansi Syariah. Eidetic Reduction Informan Nilam, bagi informan pemahaman informan tentang mata kuliah Akuntansi Syariah itu hanya akuntansi yang lebih ke agama Islam dan informan mengusulkan bahwa mata kuliah Akuntansi Syariah untuk menjadi mata kuliah pilihan.

\subsection{Persepsi Mahasiswa Sinta terhadap Akuntansi Syariah}

Pemahaman merupakan suatu kemampuan untuk mengetahui dan mengingat sesuatu dari perspektif yang berbeda, persepsi efektif yang membutuhkan kapasitas pembaca untuk menghubungkan materi teks dengan informasi yang dia miliki sekarang. Tahap ini merupakan tahap yang dilakukan peneliti untuk menggali informasi tentang bagaimana pendapat mahasiswa non muslim tentang mata kuliah Akuntansi Syariah. Seorang informan Sinta menyatakan pendapatnya:

"Menurut saya dengan adanya mata kuliah Akuntansi Syariah, [saya sebagai mahasiswa yang bukan dari agama muslim, yang dulunya tidak tau kalau misalnya ada kaya prinsip jual beli yang menerapkan prinsip murabahah itu jadi tau dengan adanya mata kuliah Akuntansi Syariah, banyak yang misalnya kaya yang sebelumnya saya tidak tau jadi saya tau dengan adanya mata kuliah ini.]"

Pernyataan awal (noema) Sinta, peneliti memperoleh bahwa Sinta, mendapatkan pengetahuan yang baru dalam mata kuliah Akuntansi Syariah. Peneliti kembali melanjutkan pertanyaan sebagai mahasiswa non muslim apa yang anda pahami setelah mempelajari mata kuliah Akuntansi Syariah. Informan Sinta mengatakan:

"lyang masih sampai sekarang itu membekas sih mengenai ini apa kerja sama.] Kaya perjanjian mudarabah begitu dimana kaya misalnya dengan perjanjian ini pihak pemilik modal itu tidak perlu menuntut ... Jadi pemilik modal dengan pengelola usaha ini sudah ada perjanjiannya kaya misalnya pembagian pemilik modal dapat 60 yang kelola usahanya sepenuhnya itu dapat 40 jadi kaya apa namanya tidak ada sistem-sistem bunga begitu sama saja saya bilang awal-awal. Eeehh, itu sih yang saya masih ingat sampai sekarang."

Menurut Pernyataan (noesis) Sinta, dapat memahami Akuntansi Syariah dengan baik hal itu dapat dilihat dari jawaban yang pada saat wawancara. Akuntansi Syariah akuntansi yang menghindari riba dan tidak mementingkan keuntungan. Informan Sinta merupakan lulusan SMK Jurusan Akuntansi yang membuat informan paham dengan adanya akuntansi, walaupun semasa SMK belum pernah mendengar Akuntansi Syariah. Peneliti melanjutkan pertanyaan apa kesulitan yang didapatkan pada saat mengikuti mata kuliah Akuntansi Syariah. Informan Sinta berpendapat bahwa:

"kesulitan itu pasti banyak karena [satu masalah Akuntansi Syariah inikan nanti pas kuliah] baru banyak juga istilah-istilahnya didalam yang sesuaisesuai syariat muslim kan yang baru pertama-pertama yang bukan dari muslim baru dengar, jadi yaa banyak kesulitan yang didapat tapikan semuanya bisa dipelajari jadi tidak terlalu menyulitkan pas mengambil mata kuliah Akuntansi Syariah, kesulitannya masih bisa diatasi.” 
Peneliti bertanya kembali bagaimana pendapat mahasiswa non muslim terhadap mata kuliah Akuntansi Syariah di masa mendatang. Pendapat informan Sinta menyatakan:

"Menurut saya [di masa mendatang lebih bagus lagi Akuntansi Syariah karena eeehh, kedepannyakan mahasiswa-mahasiswa akuntansi itu yang tentunya nanti dia pasti akan ke dunia kerja\} dengan adanya mata kuliah Akuntansi Syariah eeehh dasar pemikiran para mahasiswa-mahasiswa ini yang akan jadi calon pekerja nantinya tidak hanya memikirkan sematamata untuk memaksimalkan keuntungan ..."

"IMenurut saya tidak masalah karena bisa menjadi tambahan ilmu pengetahuan yang baru.]"

Jawaban tersebut merefleksikan epoche informan Sinta memiliki kesulitan pada istilah-istilah yang ada dalam Akuntansi Syariah. informan Sinta memiliki tanggapan positif dengan mata kuliah Akuntansi Syariah di masa mendatang bisa dijadikan dasar pemikiran mahasiswa yang akan jadi calon pekerja dan pengetahuan yang didapatkan dalam mata kuliah Akuntansi Syariah bisa menambah ilmu pengetahuan.

Intentional Analysis Informan Sinta, mendengar Akuntansi Syariah pada saat berada di bangku kuliah, menurut Sinta kesulitannya dengan adanya istilah-istilah yang baru didengar informan tetapi menurut informan di mata kuliah Akuntansi Syariah kesulitannya masih bisa diatasi. Eidetic Reduction Informan Sinta memahami mata kuliah Akuntansi Syariah karena dengan mata kuliah tersebut informan mendapatkan pengetahuan yang baru dan bisa berguna pada saat berada di lingkungan kerja nanti.

\subsection{Persepsi Mahasiswa Riri terhadap Akuntansi Syariah}

Mahasiswa terbiasa dengan pola belajar menghafal tetapi tidak memahami ilustrasi yang diberikan sehingga mahasiswa akan cenderung mudah lupa untuk mengingat apa yang telah mereka ketahui atau mengalami masalah dalam memahami apa yang akan diajarkan selanjutnya. Tahap penggalian informasi bagaimana pendapat mahasiswa non muslim tentang mata kuliah Akuntansi Syariah. Informan Riri yang beragama protestan berpendapat:

"Menurut saya mata kuliah Akuntansi Syariah itu mungkin bisa dijadikan sebagai mata kuliah pilihan ...

Pernyataan (noema) Riri peneliti memperoleh informan mengusulkan mata kuliah Akuntansi Syariah menjadi mata kuliah pilihan karena tidak semua mahasiswa non muslim mau mengikuti mata kuliah Akuntansi Syariah. Peneliti melanjutkan pertanyaan sebagai mahasiswa non muslim apa yang anda pahami setelah mempelajari mata kuliah Akuntansi Syariah. Informan yang bernama Riri menyatakan pendapatnya:

"Disini yang saya pahami tentang riba dalam Akuntansi Syariah. [Riba itu sangat bertolak belakang dengan Akuntansi Syariahl karena riba sendiri adalah pelebihan jumlah pinjaman saat pengembalian yang di bebankan kepada peminjam dan Islam sangat melarang dengan perbuatan ini."

"Hmm, saya pernah mengikuti kelas Akuntansi di kampus eehh sehingga membuat saya lebih mengerti tentang Akuntansi Syariah. [Akuntansi Syariah sangat penting karena merupakan suatu ilmu akuntansi yang mengajarkan secara langsung tidak merugikan orang lain dan sesuai dengan syariat dari agama Islam.]" 
Pernyataannya (noesis) Riri, peneliti memperoleh bahwa riba dalam Akuntansi Syariah dilarang atau diharamkan. Informan Riri berpendapat setelah mengikuti mata kuliah Akuntansi Syariah informan mendapatkan pengetahuan yang baru dalam Akuntansi Syariah. Peneliti melanjutkan pertanyaan apa kesulitan yang didapatkan pada saat mengikuti mata kuliah Akuntansi Syariah. Informan Riri mengatakan:

"kesulitannya itu karena terdapat Bahasa arab yang [saya tidak mengerti dan juga istilah-istilah dalam muslim yang baru saya dengar pada saat mata kuliah Akuntansi Syariah] seperti mudharabah dan juga istilah-istilah lainnya."

"Perkuliahan mata kuliah Akuntansi Syariah yang telah disediakan oleh pihak Jurusan Akuntansi sudah sangat baik, tetapi [menurut saya untuk masa yang akan datang sebaiknya Akuntansi Syariah itu dijadikan sebagai mata kuliah pilihan] karena tidak semua mahasiswa non muslim menerima dan mau mengikuti perkuliahan mata kuliah Akuntansi Syariah tersebut."

"[Menurut saya tidak semua mahasiswa non muslim dapat memahami dengan baik mata kuliah Akuntansi Syariah karena di mata kuliah Akuntansi Syariah terdapat huruf dan Bahasa Al-Qur'an atau Arab sehingga saya kurang memahaminya dan bagi saya Akuntansi Syariah bisa dijadikan mata kuliah pilihan bukan wajib.]"

Menurut epoche dari informan Riri, beberapa mahasiswa non muslim tidak dapat memahami mata kuliah Akuntansi Syariah dengan baik disebabkan adanya huruf dan bahasa Arab serta istilah-istilah yang belum pernah mereka dengar sebelumnya yang membuat mahasiswa non muslim kesulitan dalam mata kuliah Akuntansi Syariah. Menurut informan Riri mata kuliah Akuntansi Syariah dijadikan mata kuliah pilihan karena tidak semua mahasiswa non muslim mau menerima dan mengikuti perkuliahan. Intentional Analysis informan Riri, kesulitan dengan istilahistilah dalam Akuntansi Syariah yang baru didengar. Eidetic Reduction bagi informan Riri, Akuntansi Syariah dalam pembelajaran yang disediakan pihak Jurusan Akuntansi sudah sangat baik tetapi menurutnya tidak semua mahasiswa non muslim mau mengikuti mata kuliah tersebut.

\subsection{Persepsi Mahasiswa Eka terhadap Akuntansi Syariah}

Pemahaman merupakan tingkat kemampuan yang mengharapkan seseorang harus memiliki pilihan untuk memahami kepentingan atau gagasan, suatu keadaan dan kenyataan yang ada. Bagaimana pendapat mahasiswa non muslim tentang mata kuliah Akuntansi Syariah. Informan eka beragama Protestan dalam wawancara mengatakan:

"Eeehh, menurut pendapat saya tentang mata kuliah Akuntansi Syariah itu termaksuk [mata kuliah yang rumit untuk saya yang non muslim.]"

Berdasarkan pernyataan (noema) Eka peneliti memperoleh kesulitan informan dalam mata kuliah Akuntansi Syariah disebabkan oleh perbedaan agama yang dianutnya.Peneliti bertanya sebagai mahasiswa non muslim apa yang anda pahami setelah mempelajari mata kuliah Akuntansi Syariah. Informan Eka, berpendapat:

"Iyang saya pahami sedikit tentang mata kuliah Akuntansi Syariah tentang mudharabanya yaitu perjanjian yang dilakukan di awal.]" 
Peneliti kembali melanjutkan pertanyaan bagaimana pemahaman mahasiswa non muslim terhadap mata kuliah Akuntansi Syariah. Informan Eka menyatakan pendapatnya:

"Menurut saya sebagai non muslim itu [sulit dan lebih baik dijadikan mata kuliah pilihan.]”

Menurut Pernyataan (noesis) Eka, mudarabah yang ada dalam Akuntansi Syariah hanyalah suatu perjanjian dilakukan di awal. Informan Eka mengusulkan mata kuliah Akuntansi Syariah untuk dijadikan mata kuliah pilihan.

"Menurut saya untuk di masa mendatang saya berharap mata kuliah Akuntansi Syariah itu hanya menjadi mata kuliah pilihan karena [selama saya mengikuti perkuliahannya saya susah untuk memahami.]"

"tidak setuju, [untuk saya yang non muslim lebih baik dijadikan mata kuliah pilihan karena banyak yang kurang saya pahami.]"

Menurut epoche dari informan Eka, adanya tulisan arab dan istilah-istilah yang belum pernah mereka dengar sebelumnya yang membuat mahasiswa non muslim kesulitan dalam mata kuliah Akuntansi Syariah, adanya kesulitan dan kurangnya pemahaman mereka terhadap mata kuliah Akuntansi Syariah yang membuat informan mengusulkan bahwa mata kuliah Akuntansi Syariah untuk menjadi mata kuliah pilihan, dari pernyataan informan tampaknya informan belum terlalu paham dengan adanya mata kuliah Akuntansi Syariah. Intentional Analysis bagi informan Eka, mata kuliah Akuntansi Syariah itu mata kuliah yang sulit untuk dipahami. Selama proses perkuliahan informan susah memahami mata kuliah tersebut. Eidetic Reduction bagi informan Eka, mengalami kesulitan dalam memahami mata kuliah Akuntansi Syariah.

\subsection{Persepsi Mahasiswa Erni terhadap Akuntansi Syariah}

Peneliti bertanya bagaimana pendapat mahasiswa non muslim tentang mata kuliah Akuntansi Syariah. Seorang informan Erni yang beragama Katolik berpendapat:

"Mata kuliah Akuntansi Syariah itu kalau [menurut kita yang non muslim itu sebenarnya mata kuliahnya susah.]"

Berdasarkan pernyataan (noema) Erni peneliti memperoleh kesulitan informan dalam mata kuliah Akuntansi Syariah disebabkan oleh perbedaan agama yang dianutnya. Peneliti kembali bertanya sebagai mahasiswa non muslim apa yang anda pahami setelah mempelajari mata kuliah Akuntansi Syariah. Erni menyatakan pendapatnya:

"mata kuliah Akuntansi Syariah itu ternyata mata kuliah yang tidak mementingkan eehh dia [tidak membicarakan banyak laba lebih banyak kebagi hasil.]"

"mata kuliah Akuntansi Syariah itu sebenarnya kalau untuk kita, [kalau kita mengerti tentang istilah-istilah yang ada di dalam itu sebenarnya bagus untuk dipelajari.]"

Berdasarkan pernyataan (noesis) Erni peneliti memperoleh dalam mata kuliah Akuntansi Syariah tidak membicarakan adanya laba yang banyak tetapi lebih membicarakan bagi hasil dan mata kuliah Akuntansi Syariah bagus untuk dipelajari jika mahasiswa paham dengan istilah-istilah yang ada dalam Akuntansi Syariah. 
Peneliti kembali bertanya apa kesulitan yang didapatkan pada saat mengikuti mata kuliah Akuntansi Syariah. Erni berpendapat:

"Yang saya dapati disana [kesulitannya itu dalam istilah-istilah yang dalam sistem Syariah itu susah untuk kita pahami.]"

"Kalau menurut saya kalau bisa sih mata kuliah Akuntansi Syariah itu di [menjadi mata kuliah pilihan] jangan dijadikan mata kuliah wajib. Akuntansi Syariah sebagai mata kuliah wajib agak kurang tepat, karena tidak semua mahasiswa, khususnya yang non muslim tidak mampu mengikuti mata kuliah tersebut dengan baik. Contohnya saya terpaksa ambil mata kuliah itu karena memang diwajibkan (sambil tersenyum malumalu).]"

Jawaban tersebut merefleksikan epoche informan, tampaknya informan Erni memiliki kesulitan pada istilah-istilah yang ada dalam Akuntansi Syariah berdasarkan pernyataan yang mereka utarakan bahwa mata kuliah Akuntansi Syariah sebaiknya dijadikan mata kuliah pilihan, tampaknya informan belum terlalu paham dengan adanya mata kuliah Akuntansi Syariah. Intentional Analysis menurut informan Erni, kesulitannya pada istilah-istilah dan sistem Syariah. Eidetic Reduction menurut informan Erni, Mata kuliah Akuntansi Syariah itu susah dipahami tetapi menurut informan jika istilah-istilah dalam Akuntansi Syariah dapat dipahami maka mata kuliah Akuntansi syariah bagus untuk dipelajari.

\subsection{Analisis Hasil Penelitian Secara Menyeluruh}

Mahasiswa merupakan individu yang sedang belajar di tingkat perguruan tinggi, baik negeri maupun swasta atau instansi lain yang sebanding seperti perguruan tinggi. Mahasiswa dianggap memiliki tingkat pemikiran yang signifikan, pengetahuan dalam penalaran, penilaian, dan pemikiran penuh dalam memutuskan atau bertindak (Siswoyo, 2009). Akuntansi Syariah berawal dengan anggapan bahwa akuntansi adalah suatu substansi yang memiliki dua kekuatan, yang berarti bahwa akuntansi tidak hanya dibentuk oleh keadaannya saat ini tetapi juga memiliki kemampuan untuk memengaruhi keadaannya saat ini, termasuk perilaku manusia yang menggunakan informasi akuntansi (Bustami, 2016). Menurut Adnan (2005:70) mengandung definisi "akuntansi yang bertujuan untuk mencapai keadilan sosial ekonomi (Al Falah) dan mengenal sepenuhnya akan kewajiban kepada Tuhan, individu dan masyarakat yang berhubungan dengan pihak-pihak yang terkait pada aktivitas ekonomi seperti akuntan, manajer, auditor, pemilik, pemerintah dan sebagai sarana bentuk ibadah" (Maharani, Nuraini, dan Andrianto, 2017). Menurut Bustami (2016) Akuntansi Syariah merupakan akuntansi yang diciptakan bukan hanya dengan cara tambal sulam terhadap akuntansi konvensional, namun merupakan penyempurnaan filosofis kualitas Al-Qur'an yang dimasukkan ke dalam pemikiran teoritis dan teknis akuntansi (Padli dkk., 2019).

Berdasarkan hasil pengamatan peneliti secara menyeluruh terhadap kelima informan, terdapat anggapan dari Nilam beragama Hindu. Bagi informan pemahaman informan tentang mata kuliah Akuntansi Syariah itu hanya akuntansi yang lebih ke agama Islam dan informan mengusulkan bahwa mata kuliah Akuntansi Syariah untuk menjadi mata kuliah pilihan. Sinta yang beragama Protestan memahami mata kuliah Akuntansi Syariah karena dengan mata kuliah tersebut informan mendapatkan pengetahuan yang baru dan bisa berguna pada saat berada di lingkungan kerja nanti. Riri beragama Protestan, Akuntansi Syariah yang disediakan pihak Jurusan Akuntansi sudah sangat baik tetapi menurutnya tidak semua mahasiswa non muslim mau mengikuti mata kuliah tersebut. Eka yang beragama Katolik, Mata kuliah Akuntansi Syariah itu susah dipahami tetapi 
menurut informan jika istilah-istilah dalam Akuntansi Syariah dapat dipahami maka mata kuliah Akuntansi syariah bagus untuk dipelajari. Erni beragama Protestan, mengalami kesulitan dalam memahami mata kuliah Akuntansi Syariah.

Mahasiswa non muslim hanya melihat Akuntansi Syariah dari segi agama sehingga membuat mereka tidak tertarik dengan adanya Akuntansi Syariah karena tidak sesuai dengan agama yang dianut mereka. Mahasiswa non muslim kesulitan dalam memahami Akuntansi Syariah karena terdapat istilah-istilah di dalam Akuntansi Syariah yang belum pernah mereka dengar hasil dan pembahasan memuat jawaban atas pertanyaan penelitian, disajikan dalam bentuk diskusi/dialogis. Berdasarkan Pemahaman Akuntansi Syariah dari sudut pandang mahasiswa non muslim Program Studi S1 Akuntansi, peneliti menemukan bahwa informan Nilam, Riri, Erni, Eka, mengalami kesulitan pada Akuntansi Syariah karena terdapat istilah-istilah di dalam Akuntansi Syariah yang belum pernah mereka dengar dan adanya tulisan Al-Qur'an, sehingga informan mengusulkan bahwa mata kuliah Akuntansi Syariah untuk menjadi mata kuliah pilihan, karena pada saat mengikuti perkuliahan informan mengalami keterpaksaan.

\section{SIMPULAN}

Berdasarkan penelitian yang dilakukan oleh peneliti dapat disimpulkan bahwa pemahaman mata kuliah Akuntansi Syariah yang diberikan kepada mahasiswa non muslim terdapat kendala kurangnya pemahaman istilah-istilah dan Bahasa Arab yang digunakan dalam Akuntansi Syariah. Hasil wawancara menunjukkan pendapat yang positif mengenai mata kuliah Akuntansi Syariah, dapat memberikan pengetahuan mengenai Akuntansi yang sesuai dengan ajaran-ajaran Islam walaupun mahasiswa non muslim berpendapat mata kuliah ini sedikit sulit dipahami mereka. Di sisi lain juga terdapat pendapat yang negatif yang artinya mereka tidak tertarik dengan mata kuliah Akuntansi Syariah yang diberikan karena tidak sesuai dengan agama yang mereka anut, mereka mengikuti perkuliahan mata kuliah Akuntansi Syariah karena mata kuliah wajib sehingga mereka mengalami keterpaksaan untuk mengikuti perkuliahannya.

Keterbatasan yang dialami peneliti dalam melakukan penelitian adalah jumlah mahasiswa non muslim di Program Studi S1 Akuntansi yang lebih sedikit dibandingkan dengan mahasiswa muslim sehingga membuat peneliti membatasi penelitian dalam memilih informan dan adanya pandemi COVID 19 yang membatasi ruang lingkup selama penelitian.

Berdasarkan kesimpulan yang telah diuraikan oleh peneliti, maka peneliti mengemukakan saran untuk menerapkan pendekatan yang lebih dekat dengan mahasiswa non muslim agar dapat menemukan hambatan yang mereka hadapi dan sebaiknya pihak kampus lebih mengenalkan Akuntansi Syariah melalui seminar atau workshop tentang Akuntansi Syariah yang bersifat motivasional khusus untuk mahasiswa non muslim.

\section{REFERENSI}

Febriantoro, D. E. (2013). Persepsi Mahasiswa Akuntansi Non Muslim Terhadap Mata Kuliah Akuntansi Syariah. Jurnal Ilmiah Mahasiswa FEB, 1(2), 8-9.

Khaddafi, M., Siregar, S., Harmain, H., Nurlaila, Zaki, M., \& Dahrani. (2017). Akuntansi Syariah Meletakkan Nilai-nilai Syariah Islam dalam ilmu Akuntansi.

Lawrence, N. W. (2007). Basics of Social Research Methods: Qualitative and Quantitative Approaches (Boston (ed.)). Pearson education, Inc.

Ludigdo, U. (2009). Mengembangkan Kurikulum Akuntansi Berbasis Kewirausahaan, Syariah dan Etika: Sebuah Pengalaman. Universitas Brawijaya.

Mukhtaruddin, \& Dina, A. (2004). Persepsi Mahasiswa Akuntansi Terhadap Urgensi 
Syariah dan Relevansinya dalam Kurikulum Akuntansi. Fordema, 4 No. 1, 709724.

Pratiwi, R. (2015). Pemahaman Mahasiswa Non-Muslim Terhadap Mata Kuliah Akuntansi Syariah (Studi Kasus Di Jurusan Akuntansi STIE Multi Data Palembang). 5(1), 56-63.

Rini. (2018). Potret Pendidikan Akuntansi Syariah di Indonesia. Kajian Ekonomi Islam, 3(2), 135-143.

Sanders, P. (1982). Phenomenology: A New Way of Viewing Organizational Research (Vol. 7). Academy of Management Review.

Triyuwono, I. (2012). Akuntansi Syariah: Perspektif, Metodologi dan Teori (2nd ed.). PT RajaGrafindo Persada, Jakarta.

Wijaya, A. L. (2013). Persepsi Mahasiswa Pendidikan Akuntansi Tentang Kurikulum Akuntansi Syariah. Jurnal Akuntansi Dan Pendidikan, 2(2011), 71-84. 